Mgr Przemysław Terejko

UMCS Lublin

e-mail: przemekterejko@wp.pl

\title{
Cognitive Grammar as a Manifestation of the Pragmatic Turn in Linguistics
}

\section{Introduction}

The aim of the present article is to provide arguments in favour of the hypothesis that the theory of Cognitive Grammar (henceforth referred to as CG) as created and developed by Ronald Langacker ${ }^{1}$ can be seen as a part of a wider tendency in linguistics branded the pragmatic turn. The term appears a number of times in the literature to refer to "a shift from the paradigm of theoretical grammar (in particular syntax) to the paradigm of the language user"2. This definition contains two elements that we believe require comment. Firstly, the starting point of the turn, according to Jacob Mey, was the paradigm of theoretical grammar, which in itself is not very telling. However, the comment added in the brackets seems to draw our attention directly to the dominant framework in the linguistics of the middle of the $20^{\text {th }}$ century - Noam Chomsky's Generative Linguistics. Secondly, the direction of the turn was "the paradigm of the language user", that is, the aspects of language that, according to Chomsky, were outside the scope of linguistics proper but a subject matter of a separate branch of study, namely pragmatics. The pragmatic turn has, therefore, not only brought pragmatics into the realm of linguistics but has also put it in the spotlight, as the major topic within the field.

Our task of proving that $\mathrm{CG}$ is an important part of the turn will, therefore, involve showing that the issues of pragmatic nature play an important role in the

1 Cf. R.W. Langacker, Foundations of Cognitive Grammar, vol. 1: Theoretical Prerequisites, Stanford: Stanford University Press 1987; Idem, Cognitive Grammar: A Basic Introduction, Oxford-New York: Oxford University Press 2008.

2 J.L. Mey, Pragmatics: An Introduction, $2^{\text {nd }}$ ed., Malden-Oxford: Blackwell Publishing 2001, p. 4. 
framework. Firstly, we shall consider the position of pragmatics within the entire theory. Secondly, we shall direct our attention to a more specific level of the meanings of individual expressions. Finally, we shall consider the usage-based nature of $\mathrm{CG}$ and discuss the importance of this fact for the issue in question with examples of three linguistic phenomena: language acquisition, grammatical representation and structuring.

\section{Semantics and Pragmatics in CG}

The question of the relation between semantics and pragmatics in CG will be examined on the basis of accounts by two leading proponents of the theory, namely John Taylor and Ronald Langacker. The former approaches the issue from the historical perspective and attributes the emergence of pragmatics as a fullyfledged field of linguistic study to the dominance of Generative Linguistics in the past. According to Taylor, the reason for the appearance of pragmatics was the apparent conflict between the claim that language is a system autonomous of the world and the fact that it is used to describe and interact with this world. Pragmatics served the role of "an interface that links these otherwise independent systems" Taylor can, therefore, be said to reject the need for pragmatics in post-Chomskyan linguistics. It does not mean, however, that the existence of pragmatic phenomena is also denied. Instead, Taylor claims that "pragmatics is fully subsumed into a semantic characterisation", which means that one cannot draw any distinction between the two since every meaning, in CG at least, is context-sensitive and, in a sense, pragmatic. Moreover, the pragmatic elements of the meaning of some expressions may become conventionalised, that is, they may become a part of the semantic content. The expression Could you tell me..., for instance, is no longer understood as a question concerning a person's abilities but as a conventionalised way of making requests ${ }^{5}$. Taylor sees this property of language as a proof that semantics and pragmatics cannot be separated ${ }^{6}$.

We believe that Taylor's position diverges slightly from Langacker's as the latter does not claim that pragmatics is subsumed into semantics. In fact, he strongly refutes the accusations that the reluctance to acknowledge the existence of pragmatics stems from the fear of the theoretical problems that it might create for his

3 J.R. Taylor, Linguistic Categorization, $3^{\text {rd }}$ ed., Oxford-New York: Oxford University Press 2003, p. 133.

4 Idem, Cognitive Grammar, Oxford-New York: Oxford University Press 2002, p. 104.

5 Ibidem, p. 105.

6 Taylor says, however, that it is possible to "filter out" the pragmatic components of an utterance so that only semantic content could be dealt with. He calls such abstract construct a sentence. Ibidem. 
theory ${ }^{7}$. In reality, Langacker claims that pragmatics does exist, but it cannot be clearly separated from semantics. He says: "I do not believe that a fixed boundary between semantics and pragmatics can be drawn on a principled basis in a way that makes linguistic sense"

Such a view stems from Langacker's rejection of the principle of full compositionality that presupposes a clear distinction between the elements of the language. Instead, semantics and pragmatics are seen as occupying two opposite ends of a continuum. Every linguistic item can be placed on this scale according to what aspects of its meaning are the most prevalent in a given context.

\section{The pragmatic meanings of individual expressions}

Meaning in CG is equated with conceptualisation, that is, a particular way of structuring the relevant domains. However, the question that arises at this point is what conceptual domains should be considered relevant for a particular expression. In other words, is there a division between the strictly linguistic knowledge and extralinguistic, or pragmatic, knowledge of the world?

Langacker's stance on the matter is unequivocal, namely, no such division can be drawn. The approach that is adopted by CG is branded encyclopedic and is characterised in the following fashion: "In this approach, a lexical meaning resides in a particular way of accessing an open-ended body of knowledge pertaining to a certain type of entity"'.

Encyclopedic meaning is therefore very broad as it contains all the pieces of knowledge that are related to a given concept, or to be more precise, it contains the points of access to those pieces of information. Whether they become the part of the meaning depends on the context in which an expression is used. Some aspects of knowledge are more central and activated almost inevitably when a lexical item is used - they are responsible for the conventional semantic value of an expression. Others, in turn, are more peripheral and can be activated only in specific contexts, but this very possibility makes them a part of the lexical meaning of the expression. To use Langacker's example, the concept of [BULL] inevitably involves such pieces of information as the fact that it is a male bovine animal and maybe its general looks. But the fact that bulls are a part of a popular Spanish show and are used in rodeos can enter the meaning of the word only when such knowledge is relevant in a context ${ }^{10}$. Meaning, therefore, is not completely free as any expression invokes a limited range of knowledge together with the ways of accessing it.

\footnotetext{
7 R.W. Langacker, Cognitive Grammar..., p. 40.

8 Ibidem.

9 Ibidem, p. 39.

10 Ibidem.
} 
It is not also completely fixed as the centrality of various aspects of knowledge is a matter of degree and is susceptible to contextual factors.

Let us now consider the issues being discussed in the context of the scope of meaning. Which aspects of linguistic meaning viewed from the encyclopedic standpoint could be counted as semantic, and which as pragmatic? As we have noted above, Langacker advocates gradation between the two, but, at the same time, he states that "towards either extreme of the scale lie phenomena that are indisputably either semantic or pragmatic" ${ }^{11}$. It is therefore possible to answer the question of the scope of meaning with some precision.

The basis for doing so is the claim of variable centrality of different aspects of knowledge. To use Langacker's words: "Some [aspects of knowledge - P. T.] are so central that they can hardly be omitted from even the sketchiest characterisation, whereas others are so peripheral that they hold little significance even for the most exhaustive description" ${ }^{2}$. Those central aspects, also referred to as "core specifications" 13 , can be identified with the semantic meaning perceived from the standpoint of dictionary semantics. These are the elements of meaning that are activated if not in all then in the great majority of cases when an expression is used and constitute its "conventionally established value"14, or, as we would call it, the semantic aspect of meaning. The peripheral elements of knowledge, in turn, by virtue of their context-dependence and selective activation would lie on the pragmatic end of the continuum and constitute the pragmatic aspect of meaning.

There is, however, a terminological inconsistency in Langacker's account of the issue of the scope of meaning, which becomes apparent when we read carefully into his definition of linguistic meaning: "Besides the elements that are indisputably semantic, an expression's meaning includes as much additional structure as is needed to render the conceptualisation coherent and reflect what speakers would naively regard as being meant and said, while excluding factors that are indisputably pragmatic and not necessary to make sense of what is linguistically encoded"15. The definition contains three elements. Firstly, there are the "indisputably semantic" elements of meaning, secondly the "additional structure" responsible for contextual understanding of an expression, and finally, the excluded "indisputably pragmatic factors" that are irrelevant for the linguistic meaning. We believe that describing the linguistically irrelevant aspects of knowledge as "pragmatic" may create misunderstandings and the term seems

11 Ibidem, p. 40.

12 Idem, Foundations ..., p. 159.

13 Ibidem, p. 157.

14 Idem, Cognitive Grammar..., p. 39.

15 Ibidem, p. 42. 
more appropriately applied to the second of the mentioned elements, which should have been called "additional pragmatic structure". In such a case, the excluded content could simply be called conceptual structure.

\section{CG as a usage-based approach}

In order to fully contrast his approach with Chomsky's conception, Langacker branded his theory "a usage-based model"16 and provided three characteristics that distinguish it from the generative approach ${ }^{17}$. Those characteristics, together with the respective features of generativism, are presented in Table 1.

Table 1. The features of a usage-based theory as opposed to Generative paradigm

\begin{tabular}{|c|c|}
\hline Cognitive (usage-based) model & Generative linguistics \\
\hline Maximalism & Minimalism \\
\hline Non-reductive & Reductive \\
\hline Bottom-up & Top-down \\
\hline
\end{tabular}

After: R.W. Langacker, Concept, Image, Symbol: The Cognitive Basis of Grammar, Berlin-New York: Mouton de Gruyter 1991, p. 10.

We shall not discuss each of the characteristics here ${ }^{18}$. What we believe to be important from the point of view of our discussion is the fact that the usage-based model as characterised by the features of maximalism, non-reductiveness and bottom-up orientation is a complete reversal of the established order. In such a model, pragmatics can no longer be referred to by means of widespread and simplistic definitions such as "the study of language in use", which presuppose the autonomy of both the linguistic system and the instances of practical operation of this system. It would more appropriately be described as "the study of language from use". We believe that such a formulation more accurately reflects the directional relationship between language use and structure, with the former constituting the basis for the latter. In other words, linguistic system is nothing more than a schematisation of frequently

16 Idem, Foundations..., p. 46; Idem, Concept, Image, Symbol: The Cognitive Basis of Grammar, Berlin-New York: Mouton de Gruyter 1991, pp. 261-289.

17 According to Kemmer and Barlow, those features have become characteristic of post-Chomskyan linguistics in general. S. Kemmer, M. Barlow, A Usage-Based Conception of Language, [in:] Usage Based Models of Language, eds. M. Barlow, S. Kemmer, Stanford, CA.: CSLI Publications, Center for the Study of Language and Information 2000, p. VII.

18 For such discussion, see P. Terejko, Grice's Pragmatics in Generative and Cognitive Traditions, [in:] Visions and Revisions: Studies in Theoretical and Applied Linguistics, eds. P. Łozowski, K. Stadnik, Frankfurt am Main-Berlin-Bern-Bruxelles-New York-Oxford-Wien: Peter Lang 2016, pp. 199-207. 
occurring, similar instances of language use ${ }^{19}$. Language structure is derived from usage events by means of basic and very general psychological phenomena that govern not only our linguistic abilities but also our cognition.

The usage-based model was further developed and came to be described as "dynamic" $"$ in order to highlight its capability of accounting for "a number of the most fundamental problems in linguistics, including not only the creation and understanding of novel expressions, but also the assignment of structural descriptions, judgements of well- and ill-formedness, distributional restrictions, and differences in the degree of compositionality, productivity and generality of linguistic units"21. All these issues can be explained by a dynamic usage-based model thanks to the assumption that language and its structure are grounded in use. For the sake of illustration, Suzanne Kemmer and Michael Barlow enumerate three cases when the link is evident. Firstly, the instances of language use, also known as usage-events, are the basis for the formation of a speaker's linguistic system. Secondly, general grammatical representations are closely related to the usage events, which are their more specific instances. Thirdly, usage events are also responsible for the constant structuring and operation of the linguistic system ${ }^{22}$. We believe that a closer look at those three aspects will give us an even more precise view of the importance of language use, and consequently pragmatics, for CG.

\section{Usage-events and the acquisition of grammatical structure}

A very good example of how the usage-based conception reversed the polarity of linguistic analysis is the issue of language acquisition. Traditionally, it used to be solved by postulating the existence of an innate linguistic structure, such as Universal Grammar. This inborn knowledge structure was maximally general, which was supposed to make it possible for its empty categories to be fulfilled by the actual linguistic input, giving rise to the structure of the actual language ${ }^{23}$. The

19 Langacker refers to such individual instances of language use as usage-events and defines them as "the pairing of a vocalisation, in all its specificity, with a conceptualisation representing its full contextual understanding" (R.W. Langacker, Grammar and Conceptualization, Berlin-New York: Mouton de Gruyter 2000, p. 99). An alternative term used by Bybee and Beckner to refer to the same idea is an exemplar. See: J.L. Bybee, C. Beckner, Usage-Based Theory, [in:] The Oxford Handbook of Linguistic Analysis, eds. B. Heine, H. Narrog, Oxford-New York: Oxford University Press 2010, DOI: https://doi.org/10.1093/oxfordhb/9780199677078.013.0032, pp. 832-833.

20 R.W. Langacker, Grammar..., ch. 4.

21 S. Kemmer, M. Barlow, op. cit., p. X.

22 Ibidem, pp. II-III.

23 We refer here to the Principles and Parameters approach to the theory of Universal Grammar as summarized by Evans and Green. See V. Evans, M. Green, Cognitive Linguistics: An Introduction, Edinburgh: Edinburgh University Press 2006, pp. 143-144. 
usage-based theory of language acquisition, as advocated by Michael Tomasello ${ }^{24}$ and Heike Behrens ${ }^{25}$, rejects this assumption branded by the latter "representational nativism" 26 in favour of the "emergentist" view, in which "language can be learned from language use itself, by means of social skills like joint attention, and by means of powerful generalization mechanisms" ${ }^{\text {27 }}$. The difference between nativist and emergentist views on language acquisition is neatly phrased by Virginia Marchman and Donna Thal, who claim that in the case of the former approach, children can learn language because they "have something", and in case of the latter, because "what they have enables them to do something" children possess according to emergentism are not linguistic in nature, but they are rather the basic and very general psychological phenomena referred to above $\mathrm{e}^{29}$.

As usage-based approaches to language acquisition do not acknowledge the existence of innate linguistic structures, their basic assumption is that this structure is learned on the basis of experience, which is rich enough for all the required generalisations to be derived from it. The main thrust of the research is towards the actual processes involved in arriving at those generalisations. One of the leading proponents of the usage-based theory of language acquisition, Tomasello ${ }^{30}$ divides the phenomena into two groups. First, there are the pattern-finding abilities which enable children "to perform statistical analysis over sequences of perceptual input, including the auditory stream that constitutes spoken language" ${ }^{31}$. This set of skills allows children to arrive at abstract linguistic units from multiple instances of language use. The second set of abilities, in turn, allows them to connect the forms drawn from the use with the meanings, creating in this way fully-fledged symbolic units. This set of abilities was labelled intention-reading abilities.

24 M. Tomasello, Constructing a Language: A Usage-Based Theory of Language Acquisition, Cambridge, MA-London: Harvard University Press 2003.

25 H. Behrens, Usage-based and emergentist approaches to language acquisition, "Linguistics" 2009, vol. 47 (2), DOI: https://doi.org/10.1515/ling.2009.014, pp. 383-411.

26 Ibidem, p. 387.

27 Ibidem, p. 383.

28 V. Marchman, D. Thal, Words and Grammar, [in:] Beyond nature-nurture: Essays in honor of Elizabeth Bates, eds. M. Tomasello, D.I. Slobin, Mahwah, NJ: Lawrence Erlbaum Associates, Publishers 2005, DOI: https://doi.org/10.4324/9781410611192, p. 144.

29 Behrens adds to those cognitive abilities also the ability to work out the intentions underlying utteracnce. He calls essentially pragmatic ability "social cognition" but admits that it has not been studied in detail. H. Behrens, op. cit., pp. 395-396. The idea, however, seems analogous to Tomasello's intention-reading abilities discussed in the following part of the section.

30 Referred to here after: V. Evans, M. Green, op. cit., pp. 137-139.

31 Ibidem, p. 138. 
Tomasello's approach is, on the surface at least, compatible with Langacker' ${ }^{32}$, for whom the key cognitive ability that makes it possible for a linguistic category to emerge from the myriad of actual instances of language use is schematisation, which is defined as "the process of extracting the commonality inherent in multiple experiences to arrive at a conception representing a higher level of abstraction"33. When acquiring a linguistic category, a person compares numerous facets of experience and tries to extract the similarities that they share. At an initial stage of course, those are the most salient properties pertaining to the basic domains, such as size, colour or shape. The details, in turn, are abstracted away. The conception that is arrived at constitutes a low-level schema for this experience, which usually becomes the prototype of a newly emergent linguistic category. Usage events are, therefore, the broadest conceptual foundation that gives rise to abstract grammatical representations. But the relationship between language use and structure is a reciprocal one. On the one hand, language use is the driving force behind language structure, but on the other, language structure is also the means of categorising the use - this is precisely why language in CG is seen as "merely an inventory of units" ${ }^{\prime 34}$ rather than a powerful generator that gives as its output all and only correct expressions. Seen in such a way, language cannot itself be responsible for constructing novel structures - this must be done by the speakers by means of non-linguistic resources. What is arrived at by means of their operation is subsequently assessed with respect to the existing structure in an act of categorisation in which linguistic units serve as the standards of comparison ${ }^{35}$.

\section{Usage-events and grammatical representations}

As we have noted, linguistic categories in $\mathrm{CG}$ are seen as schematisations over more detailed, naturally occurring expressions. But language does not consist of only one level of the so-called low-level schemas. Instead, linguistic categories are understood in terms of networks, which, despite being grounded in use, gradually move up the scale of abstraction. The relation between the general patterns

32 The difference being that in Langacker's theory whole symbolic units undergo the process of schematization, therefore, they already posses the elements of meaning.

33 R.W. Langacker, Cognitive Grammar ..., p. 17.

34 Idem, Grammar..., p. 107.

35 This procedure also adequately accounts for the formation of what Bybee and Beckner call constructions, i.e. "the conventionalised strings of words or morphemes [...] that include at least one schematic position” (J.L. Bybee, C. Beckner, op. cit., p. 842). Similarly to Langacker's and Tomasello's position, such constructions "are not abstract grammatical patterns but rather they are sets of experienced exemplars arranged in cognitive space to reflect their similarity in form and meaning" (ibidem, p. 843). 
(schemas) and their instantiations can be seen as further evidence for the privileged role of language use in CG.

In order to fully apprehend the issue in question, let us investigate the notion of a schematic network as a model of linguistic categories. Langacker defines such a network as a set of nodes (vertical elements) and arcs (horizontal elements that connect the nodes). The former are just alternative ways of structuring one knowledge base by adding some unique specifications. The latter, in turn, are the categorisation relationships between nodes ${ }^{36}$. In his discussion of categorisation, Langacker treats this phenomenon as a direct consequence of the act of comparison and characterises two basic types of such a relationship. The first one is branded elaboration, or specialisation, and occurs when there is full compatibility between the schema (serving as the standard of comparison) and the target, despite the difference in the amount of detail. However, when full compatibility between the standard and the target is not achieved, the relationship is the one of extension as it involves modification of some characteristics of the target ${ }^{37}$.

The processes of elaboration and extension make a category expand both vertically and horizontally creating a network with multiple centres (called local prototypes), numerous schemas at various levels of abstraction and many extensions with various degrees of similarity to the prototypes. What is important from the point of view of our discussion, however, is the fact that at the very bottom of this highly complex and abstract structure lie usage-events, which not only make it possible for the low-level schemas to emerge but are also tied to any general representation by virtue of the fact that the meaning of an expression does not lie in just one active node but rather in the whole network, which provides a point of access to the knowledge contained in it. As a result, usage events are inevitably activated together with those representations playing a vital part in their functioning and reshaping.

\section{Usage-events and grammatical structuring}

The final piece of evidence for the importance of language use in CG is provided by the analysis of the dynamic nature of a schematic network, which, to use Langacker's words, "is shaped, maintained and modified by the pressures of language use" 38 .

One of the ways in which usage-events maintain schematic networks is simply by means of their frequent occurrence. The role of frequency and repetition for usage-based models has been highlighted by Joan Bybee and Clay Beckner ${ }^{39}$, who

36 R.W. Langacker, Foundations..., pp. 378-381.

37 Ibidem, pp. 369-373. See also: Idem, Cognitive Grammar ..., pp. 223-226.

38 Idem, Foundations..., pp. 381-382.

39 J.L. Bybee, C. Beckner, op. cit., pp. 839-842. 
analyse two basic types of frequency. The first of them is branded token frequency and refers to "the number of times an item or string occurs in running text" type has two, seemingly contradictory, effects. On the one hand, it facilitates the phonetic reduction of high-frequency items, but on the other, it makes them more resistant to change induced by productive patterns of the language ${ }^{41}$. The second kind of frequency is called type frequency and relates to the productivity of patterns and constructions. The higher the type frequency, that is, the more items can occupy a position in a pattern, the greater its productivity.

In his account of the dynamic nature of linguistic networks, Langacker also highlights the importance of the frequency of occurrence. He adds to it, however, another crucial element, namely categorisation. Each time an event occurs, it is categorised with respect to the already existing conventional units in the process of coding ${ }^{42}$. If an event is judged to be compatible with the sanctioning linguistic structure, it increases its entrenchment, that is, the cognitive routinization that affects the processing of such a structure. The conception that is entrenched the most is more likely to become the general prototype of the category. If, in turn, one of its extensions becomes entrenched to a similar extent, it may become the local prototype or even, if its application ceases to invoke the original meaning, may be perceived as an independent category. An example of such situation involves the extension of the meaning of the word star to accommodate the meaning 'celebrity'. Whenever the word is used in the metaphorical sense, the original meaning 'celestial body' is invoked, justifying the semantic extension. However, together with increasing frequency of the word used in the secondary sense, its level of entrenchment also rises so that the speakers are increasingly unaware of the metaphorical origins of the use $\mathrm{e}^{43}$. Another example is the word mail, which used to be applied only to messages sent and delivered by post, but now, by means of extension, it also refers to electronic letters. However, the categorising relationship in this case still has the unit status, which means that the connection between the two senses of the word is still widely recognised, albeit with the tendency to disappear ${ }^{44}$.

An important consequence that the influence of language use has on linguistic structure is its subjectivity ${ }^{45}$. Depending on the conditions in which categories are

40 Ibidem, p. 839.

41 The contradiction is only apparent because in the first case repetition makes the articulation of a phrase more fluent to the point that the adjacent articulatory gestures begin to overlap. In the second case, however, high frequency strengthens the memory representations of words or phrases.

42 R.W. Langacker, Foundations..., p. 382.

43 Langacker calls this process "the fading of metaphor" (ibidem, p. 386).

44 Idem, Cognitive Grammar..., p. 224.

45 The issue of subjectivity, despite being an important and broad one, is only hinted at here. For a more detailed discussion, see Idem, Subjectification, "Cognitive Linguistics" 1990, vol. 1 (1), DOI: https://doi.org/10.1515/cogl.1990.1.1.5, pp. 5-38. 
derived and used (the frequency of situations that invoke them for sanction), their structure may differ from individual to individual. Naturally, the conditions are similar for the people living in one culture, which, together with the uniform cognitive abilities possessed by human beings, accounts for the emergence of conventional units. But when we investigate the linguistic structures in close detail, no two identical structures can be found. Langacker calls such a conclusion "unfortunate, but realistic nonetheless", but also points out that the changes do not preclude successful communication for which "little more than substantial overlap" ${ }^{46}$ suffices.

\section{Conclusions}

The evidence provided in the article seems to corroborate the initial hypothesis that CG is a good example of the pragmatic turn in linguistics. Apart from the fact that it was created as an expression of dissatisfaction with Generativism, which, as we have established, was the starting point of the turn, CG expresses a profound interest in the issues of pragmatic nature, very often employing them as the basis for further investigation into the nature of language. As we have seen, the problems such as language acquisition, grammatical representations and structuring can be accounted for by means of a direct reference to the phenomena that are pragmatic in character.

\section{Streszczenie}

\section{Gramatyka kognitywna jako przejaw zwrotu pragmatycznego w językoznawstwie}

Celem artykułu jest określenie pozycji pragmatyki w teorii gramatyki kognitywnej. Autor stara się udowodnić, że teoria Ronalda Langackera wpisuje się w obraz językoznawstwa po tzw. zwrocie pragmatycznym będącym reakcją na model Noama Chomskiego. Aby potwierdzić swoją tezę, omawia różne aspekty gramatyki kognitywnej, w których przejawia się kluczowa rola pragmatyki. Przytaczane są zarówno przykłady odnoszące się do ogólnych założeń teorii (model oparty na uzusie), jak i znaczenia pojedynczych jednostek językowych (podejście encyklopedyczne).

Slowa kluczowe: gramatyka kognitywna; pragmatyka; zwrot pragmatyczny w językoznawstwie

46 Idem, Foundations..., p. 376. 


\section{Summary}

The article investigates the position of pragmatics within the theory of Cognitive Grammar. The author's aim is to verify the hypothesis that Ronald Langacker's theory fits into the picture of post-Chomskyian linguistics, which began after the so-called pragmatic turn. To support this idea, different examples of the key role of pragmatics for the framework are provided, including the ones pertaining to the general assumptions of the theory (its usage-based nature) as well as the account of the meaning of individual linguistic units (the encyclopedic approach to meaning).

Keywords: Cognitive Grammar; pragmatics; pragmatic turn in linguistics

\section{Bibliography}

Behrens H., Usage-based and emergentist approaches to language acquisition, "Linguistics" 2009, vol. 47 (2), DOI: https://doi.org/10.1515/LING.2009.014, pp. 383-411.

Bybee J.L., Beckner C., Usage-Based Theory, [in:] The Oxford Handbook of Linguistic Analysis, eds. B. Heine, H. Narrog, Oxford-New York: Oxford University Press 2010, DOI: https://doi.org/10.1093/oxfordhb/9780199544004.013.0032, pp. 827-855.

Evans V., Green M., Cognitive Linguistics: An Introduction, Edinburgh: Edinburgh University Press 2006.

Kemmer S., Barlow M., A Usage-Based Conception of Language, [in:] Usage Based Models of Language, eds. M. Barlow, S. Kemmer, Stanford, CA.: CSLI Publications, Center for the Study of Language and Information 2000, pp. VII-XXVIII.

Langacker R.W., Cognitive Grammar: A Basic Introduction, Oxford-New York: Oxford University Press 2008.

Langacker R.W., Concept, Image, Symbol: The Cognitive Basis of Grammar, Berlin-New York: Mouton de Gruyter 1991.

Langacker R.W., Foundations of Cognitive Grammar, vol. 1: Theoretical Prerequisites, Stanford: Stanford University Press 1987.

Langacker R.W., Grammar and Conceptualization, Berlin-New York: Mouton de Gruyter 2000.

Langacker R.W., Subjectification, “Cognitive Linguistics” 1990, vol. 1 (1),

DOI: https://doi.org/10.1515/cogl.1990.1.1.5, pp. 5-38.

Marchman V., Thal D., Words and Grammar, [in:] Beyond nature-nurture: Essays in honor of Elizabeth Bates, eds. M. Tomasello, D.I. Slobin, Mahwah, NJ: Lawrence Erlbaum Associates, Publishers 2005, DOI: https://doi.org/10.4324/9781410611192, pp. 141-164.

Mey J.L., Pragmatics: An Introduction, $2^{\text {nd }}$ ed., Malden-Oxford: Blackwell Publishing 2001. 
Taylor J.R., Cognitive Grammar, Oxford-New York: Oxford University Press 2002.

Taylor J.R., Linguistic Categorization, $3^{\text {rd }}$ ed., Oxford-New York: Oxford University Press 2003.

Terejko P., Grice's Pragmatics in Generative and Cognitive Traditions, [in:] Visions and Revisions: Studies in Theoretical and Applied Linguistics, eds. P. Łozowski, K. Stadnik, Frankfurt am Main-Berlin-Bern-Bruxelles-New York-Oxford-Wien: Peter Lang 2016, pp. 199-207.

Tomasello M., Constructing a Language: A Usage-Based Theory of Language Acquisition, Cambridge, MA-London: Harvard University Press 2003. 